Sains Malaysiana 49(2)(2020): 389-397

http://dx.doi.org/10.17576/jsm-2020-4902-17

\title{
Ameliorative Effect of Etlingera calophrys (K.Schum.) Rhizome Ethanolic Extract on High Fat Diet-Induced Obese Zebrafish
}

(Kesan Memperbaikkan Ekstrak Etanol Rizom Etlingera calophrys (K.Schum.) pada Diet Teraruh Tinggi Lemak Ikan Belang Obes)

\author{
LOLY SUBHIATY IDRUS, FAJAR FAKRI, RIKA HARTATI, VIENNA SARASWATY \& I KETUT ADNYANA*
}

\section{ABSTRACT}

Obesity is a major factor associated with inflammatory and various metabolic syndromes. Etlingera caloprhys, an Indonesia plant native from Southeast Sulawesi, is traditionally used years as daily food ingredient by local communities. The present paper presents an in vitro and in vivo study related to the anti-obesity effects of Etlingera caloprhys ethanol extract (ECEE). An experiment was conducted to evaluate in vitro pancreatic lipase enzyme (PLE) inhibition and in vivo anti-obesity activity in high fat diet (HFD) induced obese zebrafish fed with $10 \% \mathrm{w} / \mathrm{w}$ and $20 \% \mathrm{w} / \mathrm{w}$ ECEE-HFD were evaluated. To confirm anti-obesity activity, a set of obesity and biochemistry parameters i.e. body weight, body mass index (BMI), triglyceride and blood glucose levels, were monitored. Additionally, gene expression levels related to obesity i.e. adiponectin and PPARy in visceral adipose tissue (VAT) were also evaluated. The results showed that ECEE significantly $(p<0.05)$ inhibited PLE activity with an inhibition concentration $(I C)_{50}$ of below $100 \mu \mathrm{g} / \mathrm{mL}$. The HFD induced obese zebrafish fed with $10 \% \mathrm{w} / \mathrm{w}$ and $20 \% \mathrm{w} / \mathrm{w}$ ECEE-HFD showed decreasing body weight and BMI. The biochemistry parameters of the HFD-induced obese zebrafish fed with 10\% w/w ECEE-HFD obviously displayed optimum reduction of triglycerides and blood glucose levels. More importantly, the gene expression confirmed that ECEE suppressed adipogenesis in VAT. Hence, ECEE is suggested as a potent alternative medicine for prevention of metabolic syndromes related to obesity.

Keywords: Anti-obesity; Etlingera calophrys; pancreatic lipase; zebrafish

\section{ABSTRAK}

Keobesan adalah faktor utama yang dikaitkan dengan radang dan pelbagai sindrom metabolisme. Etlingera calophrys, tumbuhan asli Indonesia dari Sulawesi Tenggara, secara tradisinya digunakan selama bertahun-tahun sebagai bahan makanan harian oleh masyarakat tempatan. Kertas ini membentangkan kajian secara in vitro dan in vivo yang berkaitan dengan kesan anti-keobesan daripada ekstrak etanol Etlingera calophrys (ECEE). Satu uji kaji telah dijalankan untuk menilai perencatan enzim lipase pankreas (PLE) dan aktiviti anti-keobesan secara in vivo dalam diet teraruh lemak tinggi (HFD) daripada ikan zebra obes yang diberi makan 10\% w/w dan 20\% w/w ECEE -HFD telah dinilai. Untuk mengesahkan aktiviti anti-keobesan, satu set keobesan dan parameter biokimia iaitu berat badan, indeks jisim badan (BMI), trigliserida dan paras glukosa darah telah dipantau. Selain itu, tahap ekspresi gen yang berkaitan dengan keobesan iaitu adiponektin dan PPAR dalam tisu adipos visera (VAT) juga dinilai. Hasil kajian menunjukkan bahawa ECEE dengan ketara $(p<0.05)$ merencat aktiviti PLE dengan kepekatan perencatan (IC) ${ }_{50}$ di bawah $100 \mu \mathrm{g} / \mathrm{mL}$. HFD teraruh ikan zebra obes diberi makan 10\% w/w dan 20\% w/w ECEE-HFD menunjukkan penurunan berat badan dan BMI. Parameter biokimia daripada HFD teraruh ikan zebra obes yang diberi makan 10\% w/w ECEE-HFD jelas menunjukkan pengurangan optimum trigliserida dan paras glukosa darah. Lebih penting lagi, pengekspresan gen mengesahkan bahawa ECEE menghalang adipogenesis dalam VAT. Oleh itu, ECEE dicadangkan sebagai ubat alternatif yang mujarab untuk mencegah sindrom metabolik yang berkaitan dengan keobesan.

Kata kunci: Anti-keobesan; Etlingera calophrys; ikan zebra; lipase pankreas

\section{INTRODUCTION}

Obesity is a condition of excess body weight due to overconsumption of high calory-food combined with low levels of physical activity, resulting in a fat accumulation in several body parts (Baqai \& Wilding 2015). Obesity is associated with several metabolic syndromes including type 2 diabetes mellitus (T2DM), insulin resistance, dyslipidemia, cardiovascular disease, as well as atherosclerosis as an impact of adipokine secretion from adipose tissue (Cabezas et al. 2013; Redinger 2007).

Obesity is a health concern both in developed and developing countries. The World Health Organization (WHO) estimates that more than 1.9 billion adults (age 18 years and over) are overweight, and 600 million of these adults are obese (WHO 2014). In addition, about 4 million deaths globally are due to cardiovascular disease or 
diabetes mellitus associated with a high body mass index (BMI) (Afshin et al. 2017).

Orlistat is a first line conventional drug to treat obesity; however, this drug has undesirable side effects, such as nausea, vomiting, constipation, headache, insomnia, stomachache, as well as gastrointestinal disturbance (Balaji et al. 2016; Pucci \& Finner 2015). Unlike conventional drug therapy, herbal medicines have lower adverse effects (Moreira et al. 2014). Hence, natural products are expected to be safer and offer fewer side effects in treating obesity.

Etlingera calophrys (K.Schum.) A.D. Poulsen (Zingiberaceae) is also known as olae. It is native from Southeast Sulawesi, Indonesia. Traditionally, the leaves of EC are used for tightening the stomach post-partum. The rhizomes are used as spice (Ruslin \& Sahidin 2008). Sahidin et al. (2018) have explored the potency of the EC stem and have identified yakuchinone $\mathrm{A}$ as a bioactive compound with strong antioxidant activity. Interestingly, a study on yakuchinone A reported its potency to suppress gene expression related to obesity involving leptin and peroxisome proliferator-activated receptor- $\gamma$ (PPAR $\gamma$ ). Additionally, yakuchinone A also suppresses lipid accumulation during adipocyte differentiation in 3T3-L1 cells (Lin et al. 2013). Some studies have reported that different parts of the plant exhibit similar bioactivity, for example the leaves, peels and seeds from Punica granatum can potentially be used in the treatment of obesity (Hossin 2009; Lei et al. 2007; Vroegrijk et al. 2011). Thus, we hypothesized that EC rhizomes have anti-obesity activity in a similar manner as the EC stem.

Anti-obesity analysis can be carried out on a rat model or a zebrafish model. The zebrafish is a small organism that has been used in many scientific investigations related to biological activity including obesity, diabetes mellitus, dyslipidemia and atherosclerosis (Schlegel 2016; Zang et al. 2018). The advantage of utilizing zebrafish as the animal model for investigating anti-obesity is that they have approximately $70 \%$ homology with human genes and are sensitive to many pharmacological manipulations. Additionally, the use of zebrafish as the animal model is cost effective. More importantly, clinical evidence of hypolipidemic drugs exhibiting a significant hypolipidemic effect has been reported in zebrafish as well as in humans (Den Broeder et al. 2015; Kalueff et al. 2014; Leibold \& Hammerschmidt 2015; Oka et al. 2010; Zang et al. 2018; Zhou et al. 2015). These characteristics suggest that zebrafish is an excellent model for pathological studies related to the lipid metabolism. We therefore applied HFD induced obese zebrafish in our experiment. To confirm our hypothesis of EC rhizomes as an anti-obesity agent, we monitored the mean body weight, body mass index (BMI), as well as biochemistry parameters of HFD-induced obese zebrafish fed with different ECEE-HFD mixtures for 3 weeks. In addition, phytochemical screening, in vitro inhibition of pancreatic lipase enzyme (PLE), and gene expression analysis in visceral adipose tissue (VAT) of obese zebrafish were also evaluated.

\section{MATERIALS AND METHODS}

PLANT MATERIALS

Fresh rhizomes of EC were collected from Punggaluku, Southeast Sulawesi, Indonesia (in July 2018) and were identified by a taxonomist at the Herbarium Bogoriense, Research Centre for Biology, Indonesian Institute of Sciences, Bogor, Indonesia (accession number 2605/ IPH.1.01/If.07/XII/2018). The rhizomes were washed under tap water and then sliced to $1-2 \mathrm{~mm}$ width. The sliced rhizomes were then dried in a controlled oven at $45^{\circ} \mathrm{C}$. The dried EC rhizomes were grounded into powder using a grinder. The powder of the EC rhizomes was macerated in ethanol $96 \% \mathrm{v} / \mathrm{v}$ for $24 \mathrm{~h}$. This procedure was repeated three times.

\section{ANIMAL AND MAINTENANCE}

Male zebrafish age 3-5 months were used in this study. The fishes were nurtured and maintained at $28^{\circ} \mathrm{C}$ in a $14: 10$ hrs light/ dark cycle. The fishes were fed twice daily (10 $\mathrm{mg} /$ fish/day) with standard commercial dried food (Tetra Bits Complete, Korea).

\section{METHODS}

\section{IN VITRO INHIBITION OF PANCREATIC LIPASE ENZYME} (PLE) ASSAY

The in vitro inhibition of PLE assay was performed as described in Yuniarto et al. (2018). The substrate emulsion was prepared by dissolving $15 \mu \mathrm{L}$ of sesame oil and $10 \mathrm{mg}$ of BSA in phosphate buffer solution (PBS) (pH8.0) and the mixture was then sonicated for $5 \mathrm{~min}$. Subsequentially, the substrate emulsion was mixed with $50 \mu \mathrm{L}$ PLE and $10 \mu \mathrm{L}$ of sample at various concentrations $(10,20,40,60,80$ and $100 \mu \mathrm{g} / \mathrm{mL}$ ). The mixtures were then incubated (30 min, $37^{\circ} \mathrm{C}$ ). After $30 \mathrm{~min}$, the reactions were stopped by adding $3 \mathrm{~mL}$ of $1: 1(\mathrm{v} / \mathrm{v})$ chloroform and n-heptane solution. The mixtures were further centrifuged ( $2000 \mathrm{rpm}, 10 \mathrm{~min}$ ). The upper or aqueous layers were removed while the bottom layers were collected and reacted with a copper reagent. Next, the mixtures were further centrifuged (2000 rpm, 10 $\mathrm{min})$ to separate the organic layer. Finally, $0.5 \mathrm{~mL}$ of the organic layers were added with diethyldithiocarbamate- $\mathrm{Na}$ solution and the absorbances were measured at maximum $\lambda$ of $480 \mathrm{~nm}$ by using a UV-Vis spectrophotometer (Beckman coulter DU 720, California, America). The percentage of PLE inhibitory activity was calculated using the following formula:

$$
\begin{aligned}
& \% \text { PLE inhibitory activity } \\
& =\frac{\text { Absorbance control-Absorbance sample }}{\text { Absorbance control }}
\end{aligned} \times 100 \%
$$

The absorbance of control contained a mixture of enzyme and substrate, whereas the absorbance of the sample 
contained a mixture of enzyme, substrate and sample. Orlistat $0.25 \mu \mathrm{g} / \mathrm{mL}$ was used as positive standard.

\section{IN VIVO ANTI-OBESITY ASSAY}

\section{Experimental Design}

Three to five months old male zebrafish were purchased from Shifa Aquarium Bogor, West Java, Indonesia. After allowing two weeks for adaptation, the zebrafish were randomly assigned to five groups ( $n=15 /$ group): normal $\mathrm{diet} /$ negative control group, high fat diet (HFD) group, HFD at $10 \% \mathrm{w} / \mathrm{w}$ ECEE, HFD at $20 \% \mathrm{w} / \mathrm{w}$ ECEE, and orlistat (positive control group) at $0.06 \% \mathrm{w} / \mathrm{v}$. The dose of orlistat was chosen in accordance with a positive anti-obesity result prior to the experiment. The experimental design was carried out as presented in Figure 1. All groups were anesthetized under hypothermia condition before induction with HFD. Starting from the 4th week after HFD feeding, HFD-ECEE at $10 \% \mathrm{w} / \mathrm{w}$ and $20 \% \mathrm{w} / \mathrm{w}$ was fed for 3 weeks. The mean body weight and BMI were monitored once a week. After 3 weeks of HFD-ECEE feeding, the zebrafish were fasted for $14 \mathrm{~h}$ and then sacrificed under anesthesia. Blood was taken from the dorsal aorta using a heparinized needle and collected in a microtube (Landgraf et al. 2017; Meguro \& Takahiro 2018; Neia et al. 2018). All experimental procedures involving the animals were conducted in accordance with The Laboratory Zebrafish guidelines (Harper \& Lawrence 2011) and approved by the Research Ethics Committee of Padjadjaran University, Bandung, Indonesia (approval number 29/UN6.C10/ PN/2019).

\section{MEASUREMENT OF BLOOD GLUCOSE AND TRIGLYCERIDES LEVELS}

The blood glucose levels were determined using a glucometer (Autocheck, General Life Biotechnology, New Taipei, Taiwan). The serum triglyceride levels were determined using a commercial kit (Dialab-Triglyceride Kit (Dialab, Wiener Neudorf, Austria). The serum was mixed briefly with lipase and a triglyceride reaction mixture at $37^{\circ} \mathrm{C}$ for $5 \mathrm{~min}$. The absorbance was then measured at $\lambda 550 \mathrm{~nm}$ using a microplate reader.

\section{Week}
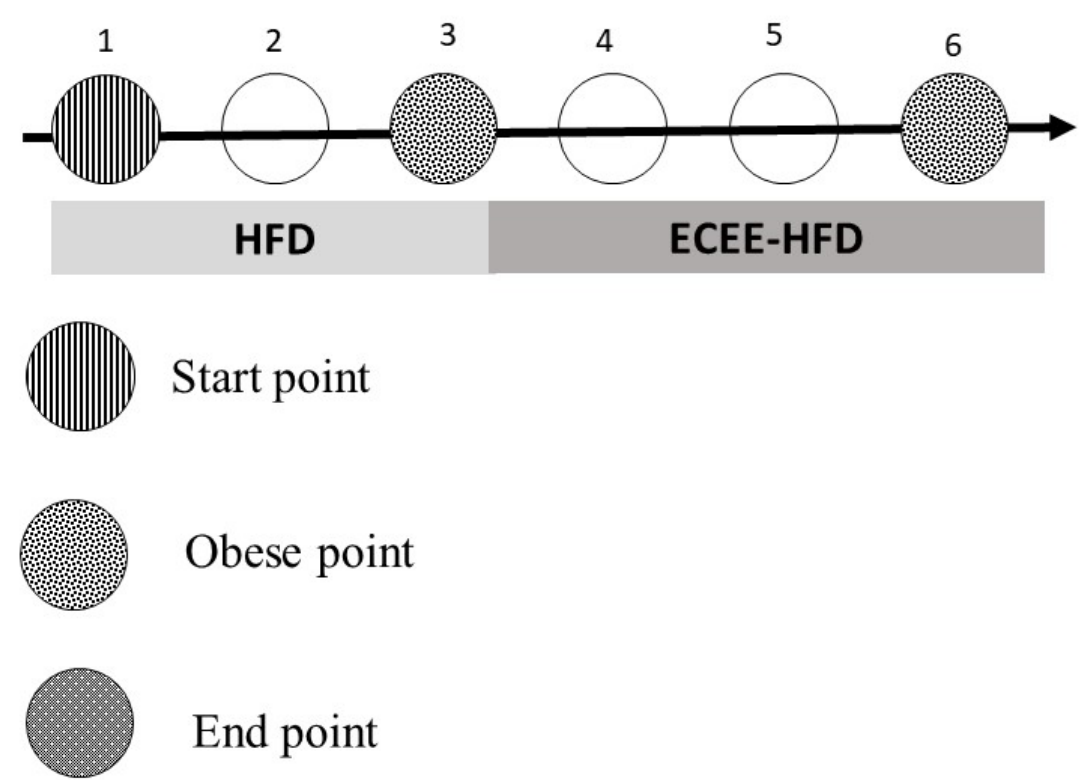

FIGURE 1. Induction and treatment design of anti-obesity activity of ECEE-HFD in HFD-induced obese zebrafish

TABLE 1. Feed ingredients of experimental diets

\begin{tabular}{lcc}
\hline Ingredients & Normal diet $(\% \mathrm{w} / \mathrm{w})$ & High fat diet $(\% \mathrm{w} / \mathrm{w})$ \\
\hline Commercial dried food & 100 & 55 \\
Corn oil & - & 20 \\
Egg yolk & - & 25 \\
\hline
\end{tabular}


mRNA EXTRACTION AND QUANTITATIVE REAL-TIME
PCR

For total RNA extraction, adipose tissues of zebrafish were immersed in RNAlater (Qiagen, Hilden, Germany) at $4^{\circ} \mathrm{C}$ for a number of days. After bead-homogenization, total RNAs were isolated using an RNAeasy mini kit (Qiagen, Hilden, Germany). cDNA synthesis from $500 \mathrm{ng}$ total RNA was performed using a ReverTra Ace qPCR RT Kit (Toyobo, Osaka, Japan). Quantitative real-time PCR (qPCR) was performed in cDNA samples using a Thunderbird SYBR qPCR mix and a qTOWER-3 real-time PCR thermal cyclers (Analytik Jena, Jena, Germany) in accordance with the manufacturer's instructions. The sequences of the sense and antisense primers used for amplifications are shown in Table 2. The relative mRNA expression levels were determined using endogenous standard ( $\beta$-actin).

\section{STATISTICAL ANALYSIS}

All data are expressed as mean $\pm \mathrm{SD}$ (standard deviation). Statistical analyses were performed using the SPSS Statistics 22 software (IBM Corporation, North Castle, New York, USA). Statistical comparisons were assessed by oneway ANOVA followed by LSD's multiple comparison test with a significance value of $\mathrm{p}<0.05$ and $\mathrm{p}<0.01$.

\section{RESULTS}

\section{PLE INHIBITORY ACTIVITY AND PHYTOCHEMICAL} SCREENING

It was showed that the ECEE inhibited PLE activity. As can be seen in Table 3, ECEE inhibited PLE in a concentration dependent manner. The ECEE inhibited PLE activity by $34.08,38.65,41.83,45.24,48.14$, and $53.89 \%$ at concentrations of $10,20,40,60,80$ and $100 \mu \mathrm{g} / \mathrm{mL}$ in vitro, respectively. Orlistat, a pancreatic lipase inhibitor used as an anti-obesity agent, inhibited the PLE enzyme activity by $51.89 \%$ at $0.25 \mu \mathrm{g} / \mathrm{mL}$. The ECEE had $\mathrm{IC}_{50}$ value of $85.15 \mu \mathrm{g} / \mathrm{mL}$. The preliminary phytochemical screening on ECEE (Table 4) obviously detected the presence of flavonoid and phenolic compounds.

\section{AMELIORATIVE EFFECT OF ECEE IN HFD-INDUCED OBESE ZEBRAFISH}

The in vitro PLE assay demonstrated the potency of ECEE as an anti-obesity agent. It was then confirmed in the animal model. As seen in Figure 2, after induction with HFD, the obese zebrafish showed enlarged abdomen (Figure 2(b)). In addition, as also shown in Figure 3, the mean body weight (Figure 3(a)) of the positive control of the HFD-

TABLE 2. Primer pair sequences, accession number and product size of the studied genes

\begin{tabular}{lcccc}
\hline Gene name & Accession Number & Forward primer & Reverse primer & Product size (bp) \\
\hline Pparg & NM_131031.2 & CGTCTTCATC CTCACTGAAC & GCAGTATTGG CACTTGTTGC & 191 \\
adipoqb & NM_001045425 & CCACTATGAT GATGTTTCCG & CTTGTCGTTC TTGTAGAGAC & 184 \\
$\beta$-act & NM_131031.2 & CCATTGAGCA CGGTATTGTG & GGTCTCGAAC ATGATCTGTG & 170 \\
\hline
\end{tabular}

TABLE 3. PLE inhibitory activity of ECEE

\begin{tabular}{lcc}
\hline Treatment & Percentage inhibition $(\%)$ & $\mathrm{IC}_{50}(\mu \mathrm{g} / \mathrm{mL})$ \\
\hline Control & - & \\
ECEE $10 \mu \mathrm{g} / \mathrm{mL}$ & $34.08 \pm 1.20^{*}$ & \\
ECEE $20 \mu \mathrm{g} / \mathrm{mL}$ & $38.65 \pm 1.75^{*}$ & 85.15 \\
ECEE $40 \mu \mathrm{g} / \mathrm{mL}$ & $41.83 \pm 4.45^{*}$ & \\
ECEE $60 \mu \mathrm{g} / \mathrm{mL}$ & $45.24 \pm 5.52^{*}$ & \\
ECEE $80 \mu \mathrm{g} / \mathrm{mL}$ & $48.14 \pm 4.40^{*}$ & $53.16 \pm 3.04^{*}$ \\
ECEE $100 \mu \mathrm{g} / \mathrm{mL}$ & $51.89 \pm 2.87^{*}$ & \\
Orlistat $0.25 \mu \mathrm{g} / \mathrm{mL}$ &
\end{tabular}

TABLE 4. Phytochemical screening of ECEE rhizome

\begin{tabular}{lc}
\hline Compound class & Present/Absent \\
\hline Alkaloids & Absent \\
Flavonoids & Present \\
Tanins & Absent \\
Phenols & Present \\
Steroids/Triterpenoids & Absent \\
Quinons & Absent \\
\hline
\end{tabular}


induced obese zebrafish group increased from $0.264 \pm$ $0.014 \mathrm{~g}$ to $0.373 \pm 0.100 \mathrm{~g}$ after week 3 , whereas after week 6 the mean body weight increased up to $0.449 \pm$ $0.078 \mathrm{~g}$. Calculation of BMI showed that the BMI values increased from $0.030 \pm 0.003 \mathrm{~g} / \mathrm{cm}^{2}$ to $0.032 \pm 0.006 \mathrm{~g} /$ $\mathrm{cm}^{2}$ and $0.035 \pm 0.006 \mathrm{~g} / \mathrm{cm}^{2}$ after week 3 for negative and positive control group, respectively (Figure 3(b)). Oka et al. (2013) state that a male zebrafish is considered obese when the BMI value is 1.1 folds greater than that of the negative control group. Our results obviously show that after week 3, the positive control of the HFD-induced obese zebrafish group had a BMI value greater by 1.2 folds than negative control group, indicating HFD caused obesity in the male zebrafish after 3 weeks of induction.

The confirmation of anti-obesity activity of ECEE was carried out in HFD-induced obese zebrafish fed with $10 \%$ $\mathrm{w} / \mathrm{w}$ and $20 \% \mathrm{w} / \mathrm{w}$ ECEE-HFD for three weeks. As shown in Figure 3, after the fourth week of the experimental period, the mean body weight (Figure 3(a)) of the HFDinduced obese zebrafish groups fed with $10 \% \mathrm{w} / \mathrm{w}$ and $20 \% \mathrm{w} / \mathrm{w}$ ECEE-HFD were $0.332 \pm 0.049$ and $0.358 \pm 0.099$ $\mathrm{g}$ with BMI values of $0.032 \pm 0.004$ and $0.034 \pm 0.007 \mathrm{~g} /$ $\mathrm{cm}^{2}$, respectively. These results obviously show an ameliorative effect on body weight compared to positive control group (mean body weight at $0.449 \pm 0.078$ and BMI at $0.039 \pm 0.005)$. The HFD-induced obese zebrafish groups fed with $10 \% \mathrm{w} / \mathrm{w}$ and $20 \% \mathrm{w} / \mathrm{w}$ ECEE-HFD for the following 2 weeks (weeks 5 and 6), clearly showed stabilization of mean body weight and BMI. More importantly, after the sixth week of the experimental period, the mean body weight and BMI of the HFD-induced obese zebrafish group fed with $20 \%$ ECEE-HFD were below of those negative control/non-diet group and similar with those of the group fed with orlistat at $0.06 \% \mathrm{w} / \mathrm{v}$.

\section{EFFECTS OF ECEE ON THE TRIGLYCERIDES AND BLOOD} GLUCOSE LEVELS

Supplementation of HFD-induced obese zebrafish with ECEE resulted a significantly $(p<0.05)$ lower levels of the serum triglycerides and blood glucose compared with that of the HFD group. As shown in Figure 4(a), 3-weeks supplementation of $10 \% \mathrm{w} / \mathrm{w}$ and $20 \% \mathrm{w} / \mathrm{w}$ ECEE reduced the triglycerides level by $40.0 \pm 1.64 \%$ and $51.4 \pm 4.53 \%$, respectively, compared with the HFD group. Whereas the blood glucose levels were reduced from $124.40 \pm 25.30$ $\mathrm{mg} / \mathrm{dL}$ to $91.60 \pm 13.3 \mathrm{mg} / \mathrm{dL}$ and $112 \pm 22.02 \mathrm{mg} / \mathrm{dL}$ in group fed with $10 \% \mathrm{w} / \mathrm{w}$ and $20 \% \mathrm{w} / \mathrm{w}$ ECEE, respectively.

\section{EFFECTS OF ECEE ON THE EXPRESSION OF LIPID METABOLISM GENES IN VISCERAL ADIPOSE TISSUE}

Effects of ECEE on the expression of lipid metabolism genes in VAT are presented in Figure 5. As shown, the expression levels of PPAR $\gamma$ (a regulator of adipocyte differentiation) were significantly $(\mathrm{p}<0.01)$ lower in the $10 \% \mathrm{w} / \mathrm{w}$ and $20 \% \mathrm{w} / \mathrm{w}$ ECEE-HFD group. In addition, as expected the expression levels of adiponectin (adipoqb, an antilipogenic protein) in were significantly $(\mathrm{p}<0.01)$ increased. Our data are similar with a study of anti-obesity activity on the HFD-induced obese zebrafish (Zang et al. 2014).

\section{DISCUSSION}

In this study, we evaluate the anti-obesity and hypolipidemic effects of ECEE in HFD induced obese zebrafish. The results showed that the mean body weight gain of the HFD group zebrafish was significantly $(p<0.01)$ higher than in the normal/negative control group, and the mean body weight
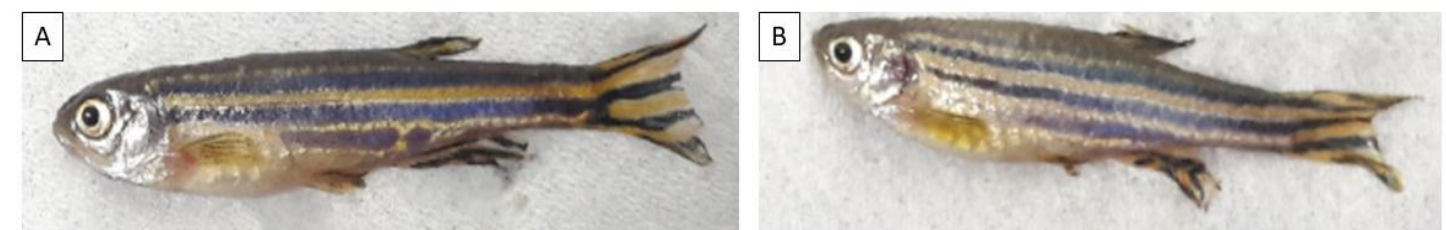

FIGURE 2. Difference in appearance of normal zebrafish (a) and HFD-induced obese zebrafish (b) after week 3 of induction
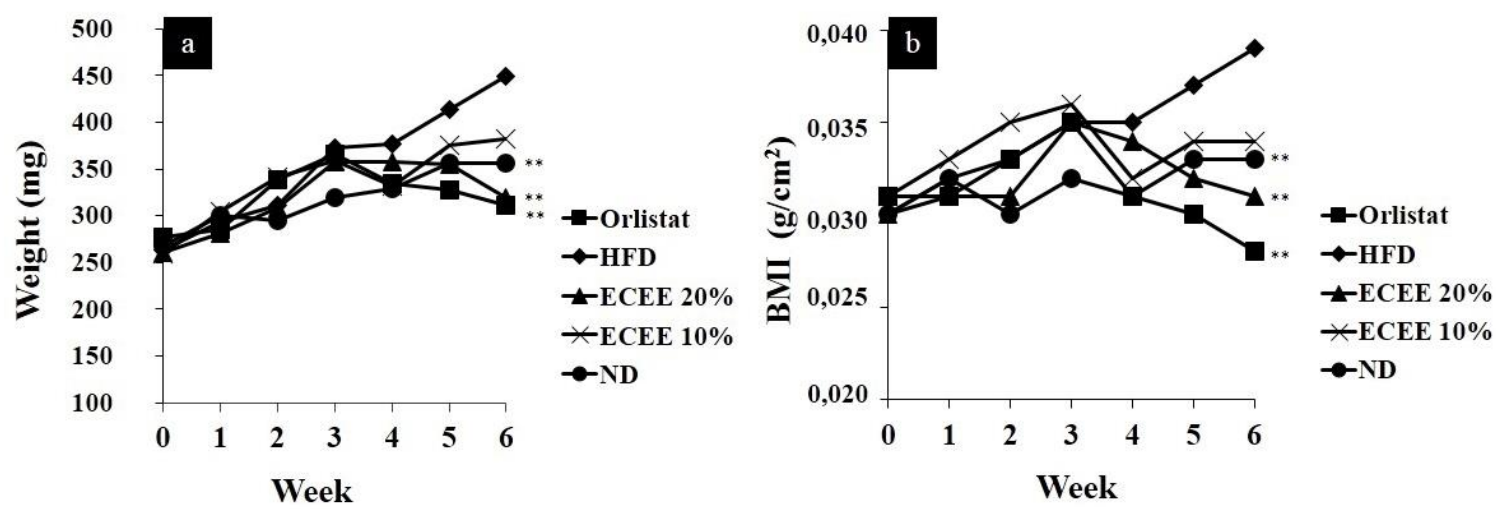

FIGURE 3. Body weight (a), BMI (b) change during experimental period for six weeks. Level of significance

$$
*=\mathrm{p}<0.05, * *=\mathrm{p}<0.01
$$



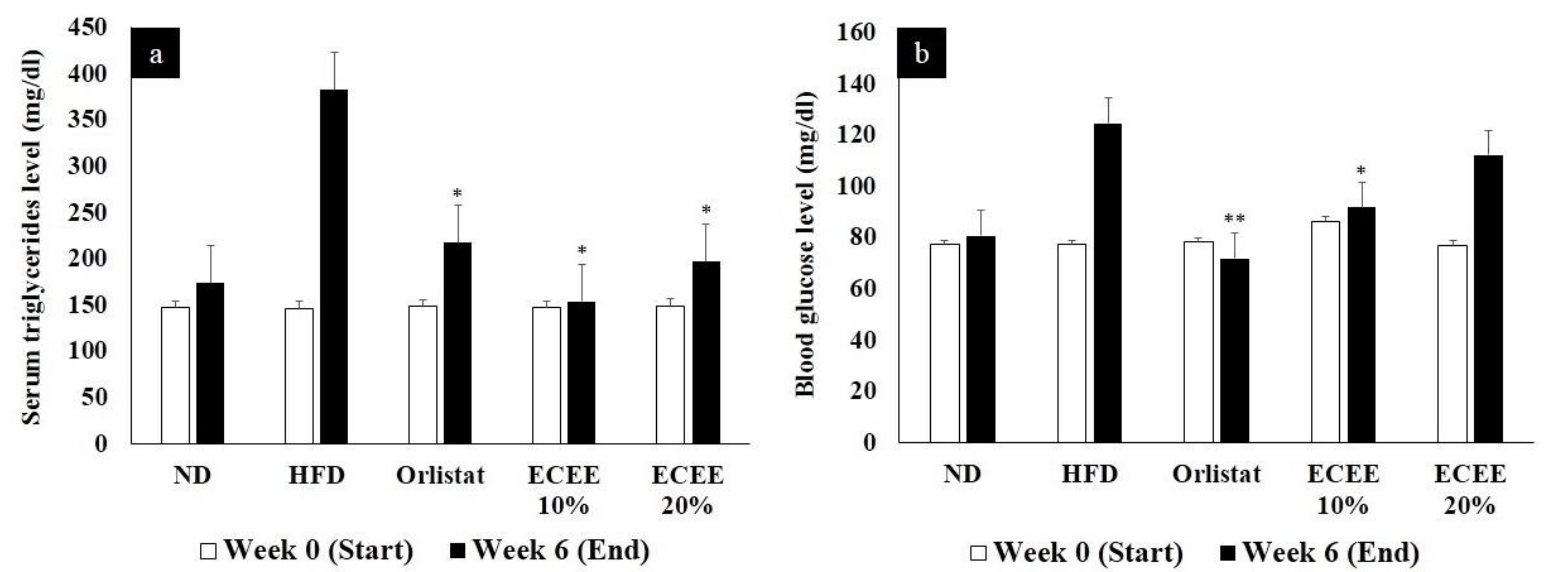

FIGURE 4. Triglyceride (a) and blood glucose (b) levels of HFD-induced obese zebrafish fed with $10 \% \mathrm{w} / \mathrm{w}$ and $20 \% \mathrm{w} / \mathrm{w}$ ECEEHFD at week 6 of the week experimental period. Level of significance $*=p<0.05, * *=p<0.01$
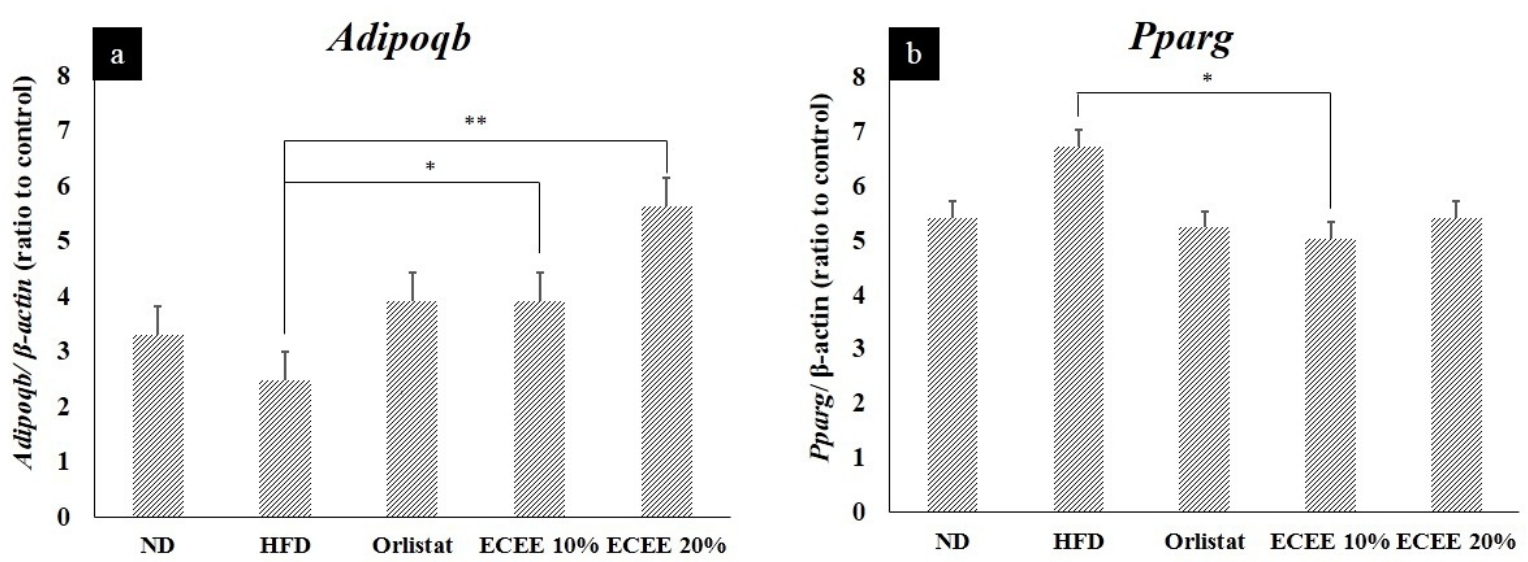

FIGURE 5. Effect ECEE on gene expression in visceral adipose tissue of zebrafish. Level of significance* $=p<0.05$ vs HFD group, ${ }^{* *}=\mathrm{p}<0.01$ vs HFD group. Adipoqb: Adiponectine b; pparg: peroxisome proliferator-activated receptor gamma

of the $10 \% \mathrm{w} / \mathrm{w}$ and $20 \% \mathrm{w} / \mathrm{w}$ ECEE-HFD groups were ameliorated to that of negative control group. There were significant differences among the groups towards HFD group (Figure 3(a)). It should be noted that the ECEE exhibits PLE inhibitory activity. When PLE is blocked, it also blocks the hydrolyzation of triglycerides, thus reducing the production as well as absorption of free fatty acids. Therefore, the ameliorative effect on mean body weight in HFD induced obese zebrafish was probably due to low absorption of free fatty acids as an impact of PLE inhibition. In addition, the anti-obesity activity of ECEE appeared to be dose dependent. On the basis of this factor, we suggest that consuming $20 \% \mathrm{w} / \mathrm{w}$ ECEE obtains the same effect with orlistat.

The presence of phenolic and flavonoid compounds was detected in ECEE. Some flavonoid and phenolic compounds including galangin, diarylheptanoid, hesperidin, neohesperidin, licochalcone, orientin, yakuchinone $\mathrm{A}$, and quercetin are reported having antiobesity potency (Buchholz \& Melzig 2015; Kumar \& Alagawadi 2013; Lin et al. 2013; Yang et al. 2014). Thus, the combination of flavonoid and phenolic compounds in ECEE could be responsible for the lower body weight gains in the ECEE groups. However, further identification and structure elucidation of the bioactive compounds in ECEE as anti-obesity agent are urgently needed.

Obesity and insulin resistance are found at an early stage of some metabolic syndromes (Klein \& Romijn 2017). Under high fat feeding or obesity condition, the release of free fatty acids from adipocytes promotes hepatic gluconeogenesis, then decreasing blood glucose disposal and inducing insulin resistance (Czech 2017; Storlien et al. 1986). The presence of insulin resistance can induce metabolic syndromes such as obesity, T2DM, and dyslipidemia (Choi et al. 2016; Czech 2017; Landgraf et al. 2017). Hence, to confirm this relationship and the potency of ECEE to prevent metabolic syndrome, we also evaluated the biochemistry parameters, i.e. the serum triglycerides and blood glucose levels. As shown in Figure 4, the HFD induced obese zebrafish obviously displayed an increment of serum triglycerides and blood glucose levels after the sixth week. The HFD induced obese zebrafish groups fed with $10 \% \mathrm{w} / \mathrm{w}$ and $20 \% \mathrm{w} / \mathrm{w}$ ECEEHFD displayed a significant $(p<0.05)$ reduction of triglycerides and blood glucose levels. This indicates that consumption of ECEE decreased triglycerides level by 
reducing production of free fatty acid and excreting lipid accumulation as the results of PLE inhibition. Therefore, consumption of ECEE increased the blood glucose disposal, as normalization impact of serum triglycerides level as well as insulin sensitivity. A direct comparison between the HFD-induced obese zebrafish groups fed with $10 \% \mathrm{w} / \mathrm{w}$ and $20 \% \mathrm{w} / \mathrm{w}$ ECEE-HFD clearly showed that the group fed with $10 \% \mathrm{w} / \mathrm{w}$ ECEE-HFD had better reduction of blood glucose levels. The pharmacology activities of natural product extract can result from synergistic, additive, or antagonistic compounds consist in the extract. Hence, the greater blood glucose lowering effect of ECEE at $10 \% \mathrm{w} / \mathrm{w}$ is probable due to less antagonistic compound content consists in ECEE (Caesar \& Cech 2019).

Supplementation of $10 \% \mathrm{w} / \mathrm{w}$ and $20 \% \mathrm{w} / \mathrm{w}$ ECEEHFD shows reduction of triglycerides level (Figure 4(a)), attenuation mRNA expression of PPAR $\gamma$ (a lipid peroxidation marker) and increment of adiponectin (Figure 5) in HFD induced zebrafish. PPAR $\gamma$ is a master regulator and a transcriptional factor that is involved in the last stage of adipogenesis. Consumption HFD promotes production of free fatty acids and triglycerides in adipose tissue (AT) (Kersten 2001), thus, increasing PPAR $\gamma$ gene expression in obesity. When PPAR $\gamma$ gene expression increases, adiponectin expression is further reduced (Balsan et al. 2015; Grygiel-Gorniak 2014). It is also known that PPAR $\gamma$ is largely expressed in adipose tissue and important for regulation of adipose tissue lipid metabolism in muscle and liver. Our data demonstrate the potency of ECEE decreasing triglycerides accumulation and cascading of the transcriptional factor, i.e. PPAR $\gamma$ at the mRNA, which makes it capable of preventing metabolic syndromes by targeting adipogenesis (Balsan et al. 2015; Inoue et al. 2005; Nakayama et al. 2018; Park et al. 1997; Sikder et al. 2018; Tian et al. 2013).

Some flavonoids are reported could improve dyslipidemia, partially by regulating fatty acids and cholesterol metabolism through decreasing adipocytes PPAR $\gamma$ expression in T2DM. In the basis of the presence of flavonoid and phenolic compounds, we propose that molecular mechanism of dyslipidemia attenuation of ECEE is partially by inhibition of PLE and targeting PPAR $\gamma$. Overall, our results recommend that ECEE can be considered as a potential alternative treatment for controlling obesity as well as related diseases including T2DM and cardiovascular.

\section{CONCLUSION}

In conclusion, based on physiological, biochemical, in vitro and in vivo analyses, this study demonstrated that ethanolic extract of EC rhizome has potent anti-obesity activities. ECEE exerts anti-obesity effects by inhibiting lipase enzyme activity. The proposed molecular mechanism is adiponectin and PPAR $\gamma$ targeting. Finally, we suggest that ECEE can be used as a potential therapeutic alternative for the treatment of obesity.

\section{ACKNOWLEDGEMENTS}

This research was supported by Riset KK-A ITB 2019. The authors thank the Department of Animal Production and Technology - Bogor Agricultural University (IPB) and The School of Pharmacy ITB to using their facilities.

\section{REFERENCES}

Afshin, A., Forouzanfar, M.H. \& Reitsma, M.B. 2017. Health effects of overweight and obesity in 195 countries over 25 years. New England Journal of Medicine 377(1): 13-27.

Balaji, M., Ganjayi, M.S., Hanuma, G.E., Parim, B.N., Mopuri, R. \& Dasari, S. 2016. A review on possible therapeutic targets to contain obesity: The role of phytochemicals. Obesity Research \& Clinical Practice 10(4): 363-380.

Balsan, G.A., Vieira, J.L., Oliveira, A.M. \& Portal, V.L. 2015. Relationship between adiponectin, obesity and insulin resistance. Revista da Associacao Medica Brasileira 61(1): 72-80.

Baqai, N. \& Wilding, J.P.H. 2015. Pathophysiology and aetiology of obesity. Medicine 43(2): 73-76.

Buchholz, T. \& Melzig, M.F. 2015. Polyphenolic compounds as pancreatic lipase inhibitors. Planta Medica 81(10): 771783.

Cabezas, M.C., Klop, B. \& Elte, J.W.F. 2013. Dyslipidemia in obesity: Mechanisms and potential targets. Nutrients 5(4): 1218-1240

Caesar, L.K. \& Cech, N.B. 2019. Synergy and antagonism in natural product extracts: When $1+1$ does not equal 2 . Natural Product Reports 36: 869-888.

Choi, B.K., Park, S.B., Lee, D.R., Lee, H.J., Jin, Y.Y., Yang, S.H. \& Suh, J.W. 2016. Green coffee bean extract improves obesity by decreasing body fat in high-fat diet-induced obese mice. Asian Pacific Journal of Tropical Medicine 9(7): 635-643.

Czech, M.P. 2017. Insulin action and resistance in obese and type 2 diabetes. Nature Medicine 23(7): 804-814.

Den Broeder, M.J., Kopylova, V.A., Kamminga, L.M. \& Legler, J. 2015. Zebrafish as a model to study the role of peroxisome proliferating-activated receptors in adipogenesis and obesity. PPAR Research 358029: 1-11.

Grygiel-Gorniak, B. 2014. Peroxisome proliferator-activated receptors and their ligands: Nutritional and clinical implications-A review. Nutrition Journal 13: 1-10.

Harper, C. \& Lawrence, Z. 2011. The Laboratory Zebrafish. New York: Taylor and Francis Group.

Hossin, F.L.A. 2009. Effect of pomegranate (Punica gratum) peels and its extract on hypercholesterolemic rats. Pakistan Journal of Nutrition 8(8): 1251-1257.

Inoue, M., Ohtake, T., Motomura, W., Takahashi, N., Hosoki, Y., Miyoshi, S., Suzuki, Y., Saito, H., Kohgo, Y. \& Okumura, T. 2005. Increased expression of PPARgamma in high fat diet-induced liver steatosis in mice. Biochemical and Biophysical Research Communications 336(1): 215-222.

Kalueff, A.V., Stewart, A.M. \& Gerlai, R. 2014. Zebrafish as an emerging model for studying complex brain disorders. Trends in Pharmacological Sciences 35(2): 63-75.

Kersten, S. 2001. Mechanism of nutritional and hormonal regulation of lipogenesis. EMBO Reports 2(4): 282-286.

Klein, S. \& Romijn, J.A. 2017. Williams Textbook of Endocrinology. 13th edition. California: Elsevier. 
Kumar, S. \& Alagawadi, K.R. 2013. Anti-obesity effects of galangin, a pancreatic lipase inhibitor in cafeteria diet fed female rats. Pharmaceutical Biology 51(5): 607-613.

Landgraf, K., Schuster, S., Meusel, A., Garten, A., Riemer, T., Schleinitz, D., Kies, W. \& Korner, A. 2017. Short-term overfeeding of zebrafish with normal or high-fat diet as a model for the development of metabolically healthy versus unhealthy obesity. BMC Physiology 17(4): 1-10.

Lei, F., Zhang, X.N., Wang, W., Xing, D.M., Xie, W.D., Su, H. \& Du, L.J. 2007. Evidence of anti-obesity effects of the pomegranate leaf extract in high-fat diet induced obese mice. International Journal of Obesity 31(6): 1023-1029.

Leibold, S. \& Hammerschmidt, M. 2015. Long-term hyperphagia and caloric restriction caused by low- or high-density husbandry have differential effects on zebrafish postembryonic development, somatic growth, fat accumulation and reproduction. PLOS ONE 10(3): e0120776.

Lin, R.J., Yen, C.M., Chou, T.H., Chiang, F.Y., Wang, G.H., Tseng, Y.P., Wang, L., Huang, T.W., Wang, H.C., Chan, L.P., Ding, H.Y. \& Liang, C.H. 2013. Antioxidant, anti-adipocyte differentiation, antitumor activity, and anthelmintic activities against Anisakis simplex and Hymenolepis nana of yakuchinone A from Alpinia oxyphylla. BMC Complementary Alternative Medicine 13: 237.

Meguro, S. \& Takahiro, H. 2018. Fish oil suppresses body fat accumulation in zebrafish. Zebrafish 15(1): 27-32

Moreira, D.L., Teixeira, S.S., Monteiro, M.H.D., De-Oliveira, A.C.A.X. \& Paumgartten, F.J.R. 2014. Traditional use and safety of herbal medicines. The Brazilian Journal of Pharmacognosy 24(2): 248-257.

Nakayama, H., Shimada, Y., Zang, L., Terasawa, M., Nishiura, K., Matsuda, K., Toombs, C., Langdon, C. \& Nishimura, N. 2018. Novel anti-obesity properties of Palmaria mollis in zebrafish and mouse models. Nutrients 10(10): 1-16.

Neia, V.B.M.J.C., Albuquerque, E.P.A., Figueiredo, I.L., Silva, T.C., Lewandowski, V., Almeida, F.L.A., Ribeiro, R.P., Visentainer, J.E.L. \& Visentainer, J.V. 2018. Effect of peanut addition to the cafeteria diet on adiposity and inflammation in zebrafish (Danio rerio). Food and Agricultural Immunology 29(1): 762-775.

Oka, T., Nishimura, Y., Zang, L., Hirano, M., Shimada, Y., Wang, Z., Umemoto, N., Kuronayagi, J., Nishimura, N. \& Tanaka, T. 2010. Diet-induced obesity in zebrafish shares common pathophysiological pathways with mammalian obesity. BMC Physiology 10(21): 1-13.

Park, K.S., Ciaraldi, T.P., Abrams-Carter, L., Mudaliar, S., Nikoulina, S.E. \& Henry, R.R. 1997. PPAR-gamma gene expression is elevated in skeletal muscle of obese and type II diabetic subjects. Diabetes 46(7): 1230-1234.

Pucci, A. \& Finer, N. 2015. New medications for treatment of obesity: Metabolic and cardiovascular effects. Canadian Journal of Cardiology 31(2): 142-152.

Redinger, R.N. 2007. The pathophysiology of obesity and its clinical manifestations. Gastroenterology \& Hepatology 3(11): 856-863.

Ruslin \& Sahidin, I. 2008. Identification and determination of traditional medicinal plants of Southeast Sulawesi People at Arboretum Prof. Mahmud Hamundu Haluoleo University (In Indonesian). Indonesian Journal of Pharmacy 19(2): 101-107.
Sahidin, Wahyuni, Muhammad Hajrul Malaka, Jabbar A., Imran. \& Marianti A. Mangaau. 2018. Evaluation of antiradical scavenger activity of extract and compounds from Etlingera calophrys stems. Asian Journal Pharmaceutical Clinical Research 11(2): 238-241.

Schlegel, A. 2016. Zebrafish models for dyslipidemia and atherosclerosis research. Frontiers in Endocrinology 7: $1-8$.

Sikder, K., Shukla, S.K., Patel, N., Singh, H. \& Rafiq, K. 2018. High fat diet upregulates fatty acid oxidation and ketogenesis via intervention of PPAR- $\gamma$. Cellular Physiology and Biochemistry 48(3): 1317-1331.

Storlien, L.H., James, D.E., Burleigh, K.M., Chisholm, D.J. \& Kraegen, E.W. 1986. Fat feeding causes widespread in vivo insulin resistance, decreased energy expenditure, and obesity in rats. American Journal of Physiology 251(5): 576-583.

Tian, C., Ye, X., Zhang, R., Long, J., Ren, W., Ding, S., Liao, D., Jin, X., Wu, H., Xu, S. \& Ying, C. 2013. Green tea polyphenols reduced fat deposits in high fat-fed rats via erk1/2-PPARc-adiponectin pathway. PLoS ONE 8(1): e53796.

Vroegrijk, I.O., van Diepen, J.A., van den Berg, S., Westbroek, I., Keizer, H., Gambelli, L., Hontecillas, R., BassaganyaRiera, J., Zondag, G.C., Romijn, J.A., Havekes, L.M. \& Voshol, P.J. 2011. Pomegranate seed oil, a rich source of punicic acid, prevents diet-induced obesity and insulin resistance in mice. Food and Chemical Toxicology 49(6): 1426-1430.

World Health Organization. 2014. Obesity and Overweight. Fact sheet No. 311. Geneva, Switzerland

Yang, M.H., Chin, Y.W., Yoon, K.D. \& Kim, J.W. 2014. Phenolic compounds with pancreatic lipase inhibitory activity from Korean yam (Dioscorea opposita). Journal of Enzyme Inhibition Medicinal Chemistry 29(1): 1-6.

Yuniarto, A., Sukandar, E.Y., Fidrianny, I., Setiawan, F. \& Adnyana, I.K. 2018. Antiobesity, antidiabetic, and antioxidant activities of Senna (Senna alexandrina Mill) and pomegranate (Punica gratum L.) leaves extracts and its fractions. International Journal of Pharmaceutical and Phytopharmacological Research 8(3): 18-24.

Zang, L., Maddison, L.A. \& Chen, W. 2018. Zebrafish as a model for obesity and diabetes. Frontiers in Cell and Developmental Biology 6: 1-13.

Zang, L., Shimada, Y., Kawajiri, J., Tanaka, T. \& Nishimura, N. 2014. Effects of yuzu (Citrus junos Siebold ex Tanaka) peel on the diet-induced obesity in a zebrafish model. Journal of Functional Foods 10: 499-510.

Zhou, J., Xu, Y.Q., Guo, S.Y. \& Li, C.Q. 2015. Rapid analysis of hypolipidemic drugs in a live zebrafish assay. Journal of Pharmacological and Toxicological Methods 72: 47-52.

Loly Subhiaty Idrus, Fajar Fakri \& I Ketut Adnyana* Department of Pharmacology and Clinical Pharmacy School of Pharmacy

Institute of Technology Bandung, Bandung

Indonesia

Rika Hartati

Department of Pharmaceutical Biology

School of Pharmacy

Institute of Technology Bandung, Bandung Indonesia 
Vienna Saraswaty

Research Unit for Clean Technology

Indonesian Institute of Sciences, Bandung

Indonesia
*Corresponding author; email: ketut@fa.itb.ac.id

Received: 19 August 2019

Accepted: 30 October 2019 
